\title{
EXPLORING THE OUTER LIMITS: THE ANTON PILLER ORDER IN CANADA
}

\author{
GEORGE TAKACH*
}

\begin{abstract}
A study of the Anton Piller order, an exceptional form of injunctive relief, in the Canadian context and an assessment of its effectiveness as a remedy for the violation of an intellectual property right.
\end{abstract}

\section{NATURE AND ORIGIN}

The Anton Piller order is an exceptional form of injunctive relief which is very similar to a private search warrant. Rooted in ancient Chancery practice possibly rising out of the industrial revolution, ${ }^{1}$ its recent emergence parallels the spiralling technological advances of the last decade. In an early form, it authorized the inspection of a bobbinmaking machine allegedly infringing on a plaintiff's letters patent ${ }^{2}$ its modern use also focuses on intellectual property cases but is gradually expanding into other areas of litigation. This is significant because an ex parte search and seizure order made in camera ". . . appears . . . to be draconian"' 3 and ". . . is at the extremity of [the] court's powers." 4 This paper proposes to examine the order in a Canadian context with a view to determining its effectiveness as a remedy for the violation of an intellectual property right in this jurisdiction.

The essentials of the Anton Piller order are as follows: ${ }^{5}$

Although this order has several variants its most stringent form, which is granted ex parte, is unique. It allows the plaintiff, with its solicitor, to enter the defendant's premises during normal business hours, show the defendant a copy of the order and search the premises for the documents or materials mentioned in the order. If any of these materials are found, the plaintiff may remove them for safekeeping pending the normal discovery process and trial. The order is an extremely powerful one. It is of use where it is expected that the material sought to be seized may disappear or be secreted prior to discovery of documents. Although its primary use has been in copyright and related areas, it can and has been of use in any area where this suspicion justifiably arises. The order does not depend upon a proprietary interest. The sine qua non of the order is the need to protect vital material from possible destruction.

As no rule of the Supreme court of England authorized the issuing of such an order without notice to the defendant, there was scant precedent for E.M.I. v. Pandit, ${ }^{6}$ a 1974 decision of the Chancery Division which granted an ex parte order enabling the plaintiff copyright owner to enter the defendant's premises and search for infringing copies. The Court purported to act pursuant to O. 29, r. 2 of the Supreme Court Rules, ${ }^{7}$ which authorized the inspection and preservation of property in another's possession and premises. However, that Rule requires an ap-

- Articling with the firm of Cruickshank, Phillips of Edmonton.

1. M. Lazarides, "Anton Piller Orders: The New Weapon With Which to Combat Piracy and Bootlegging in the United Kingdom"' (1981) 56 C.P.R. (2d) 17 at 18-19.

2. Browne v. Moore (1816) 3 Bli. 178; 4 E.R. 571.

3. E.M.l.v. Pandit [1975] I All E.R. 418 at 421 (Ch.D.).

4. Anton Piller K.G.v. Manufacturing Processes Ltd. [1976] I All E.R. 779 at 784 (C.A.).

5. E. Meyers, "Search and Seizure in Civil Cases: The Anton Piller Order" (1984) 42 The Advocate 41.

6. Supran. 3.

7. Rules of the Supreme Court 1965, S.I. 1965, No. 1776 as am. 
plication for such an order to be made by notice $(0.25$, r. 7$)$ or summons (O. 52, r. 3), both of which require service on the defendant. This did not deter the Court. Templeman J. (as he then was) stated: ${ }^{8}$

Nevertheless, in my judgment, if it appears that the object of the plaintiffs' litigation will be unfairly and improperly frustrated by the very giving of the notice which is normally required to protect the defendant, there must be exceptional and emergency cases in which the court can dispense with the notice and, either under power in the rules to dispense with notice or by the exercise of its inherent jurisdiction, make such a limited order, albeit ex parte, as will give the plaintiffs the relief which they would otherwise be unable to obtain.

His Lordship cited two cases from the last century as authority for the proposition that the court's power to issue an inspection and seizure order derives from the necessity of adapting to emergencies to make its jurisdiction effectual. ${ }^{9} \mathrm{He}$ also referred to a trilogy of unreported English cases decided between the spring and fall of $1974,{ }^{10}$ noting that their expeditious nature made written judgments impossible. Accordingly, he ordered the defendant to permit the plaintiff, its solicitor and no more than three other authorized parties to enter the defendant's premises unannounced between 8:00 a.m. and 9:00 p.m. and conduct a search and seizure for the infringing material and related documents named in the order."

It was left for the next case considering the new order to provide it with a name and consolidated guidelines for its application. In Anton Piller K.G. v. Manufacturing Processes Ltd., Lord Denning M.R. confirmed the court's inherent jurisdiction over the matter ${ }^{12}$ and Ormrod L.J. provided the following of t-quoted test:

There are three essential preconditions for the making of such an order, in my judgment. First, there must be an extremely strong prima facie case. Secondly, the damage, potential or actual, must be very serious for the plaintiff. Thirdly, there must be clear evidence that the defendants have in their possession incriminating documents or things, and that there is a real possibility that they may destroy such material before any application inter partes can be made.

The Court also took care to emphasize that the fledgling order was not a search warrant, ${ }^{14}$ but this distinction has been criticized as "judicial double-thinking" ${ }^{15}$ since the two have a similar practical effect. ${ }^{16}$ The Anton Piller case was followed by a proliferation of similar applications in the English courts, many of them successful. ${ }^{17}$

8. Supra n. 3 at $\mathbf{4 2 2 .}$

9. United Company of Merchants v. Kynaston (1821) 3 Bli. 153 at 165; 4 E.R. 561 at 565 (H.L.); Hennesseyv. Rohmann, Osborne \& Co. [1877] W.N. 14 (H.C.J.).

10. A \& $M$ Records Inc. v. Darakdjian, unrep. May 21, 1974 per Foster J.; E.M.I. Ltd. v. Khazan, unrep. July 3, 1974 per Foster J.; Pall Europe Lıd. v. Microflex Ltd., unrep. October 28, 1974 per Goff J.

11. Supran. 3 at 424 .

12. Supran. $\mathbf{4}$ at $\mathbf{7 8 3 .}$

13. Id. at 784 .

14. Id. at 782-84.

15. Supran. 1 at 26.

16. Thermax Ltd. v. Schott Ind. Glass Ltd. [1981] F.S.R. 289 at 291 (Ch.D.).

17. eg. Universal City Studios Inc. v. Mukhtar \& Sons [1976] 2 All E.R. 330 (Ch.D.); Carlin Music Corp. v. Collins [1979] F.S.R. 548 (C.A.); Protector Alarms Lıd. v. Maxim Alarms Ltd. [1978] F.S.R. 442 (Ch.D.); Ex parte Island Records Ltd. [1978] 3 All E.R. 824 (C.A.); Hallmark Cards Inc. v. Image Arts Ltd. [1977] F.S. R. 150 (C.A.). 


\section{ANTON PILLER ACROSS THE ATLANTIC}

\section{A. JURISDICTION}

The jurisdiction of Canadian courts to grant Anton Piller orders poses less of a dilemma than the one facing the Chancery Division in E.M.I. v. Pandit. At the national level, the Federal Court of Canada has no inherent jurisdiction since it is a creature of statute. ${ }^{18}$ Under s. 20 of the Federal Court Act, ${ }^{19}$ the Trial Division has concurrent jurisdiction to grant relief under any Act of Parliament, at law or in equity concerning patents, copyright, trade marks and industrial design and exclusive jurisdiction over disputes concerning applications and registration. The Court has the discretion to award injunctive relief ${ }^{20}$ as well as permit inspection ${ }^{21}$ and seizure, ${ }^{22}$ which, like the injunction, ${ }^{23}$ may be made without notice in cases of emergency. ${ }^{24}$ Since s. 20 does not confer the right to relief, it is open to other legislation to take additional jurisdiction over remedies. ${ }^{25}$ Thus, the above areas of intellectual property may also be dealt with by the Alberta courts, which have the discretion to issue injunction $\mathrm{s}^{26}$ and authorize entry into any land or building as well as the inspection, detention and preservation of property subject to an action. ${ }^{27}$ Although such orders require notice to any affected parties, they may be made ex parte if the court is satisfied that the delay caused by giving notice might entail serious mischief. ${ }^{28}$ There are similar provisions in other provincial legislation. ${ }^{29}$

\section{B. CANADIAN CASES}

The Anton Piller order made its Canadian debut in Sony Corporation v. Makers International. ${ }^{30}$ No written reasons were delivered, but the essence of the order granted ex parte and in camera by Cattenach J. has been summarized as follows: ${ }^{31}$

18. R. v. Saskatchewan Wheat Pool (1978) 81 D.L.R. (3d) 459 at 460 (F.C.T.D.); Pannu v. Minister of Employment \& Immigration [1983] 1 F.C. 204 at 206 (T.D.).

19. Federal Court Act, R.S.C. 1970 (2nd Supp.), c. 10.

20. Id. s. 44.

21. Federal Court Rules, C.R.C. 1978, c. 663, R. 471(2).

22. Id. R. $471(1)$.

23. Id. R. 469(2); Breuvage Lucky One Inc. v. L.B.G. Dist. Ltd. (1971) 64 C.P.R. 226 at 228-29 (Ex.Ct.).

24. Supra n. 21, R. 470(2).

25. Radio Corp. of America v. Philco Corp. [1966] S.C.R. 296; affg. [1965] 2 Ex.C.R. 197 at 214.

26. Judicature Act, R.S.A. 1980, c. J-1, s. 13(2); Alberta Rules of Court, Alta. Reg. 390/68, R. 440.

27. Id. R. 468 .

28. Id. R. $387(1)$.

29. For example: Judicature Act, R.S.O. 1980, c. 223, s. 19(1) and Ontario Rules of Practice, Rs. 213, 369, 372; Judicature Act, S.N.S. 1972, c. 2, s. 39(7) and Nova Scotia Civil Procedure Rules, Rs. 24.01(1), (2), 37.04(3).

30. Sony Corporation v. Makers International, unrep. June 25, 1981 (F.C.T.D.), No. T-329881 .

31. J. Cohen, "Anton Piller to the Rescue - Ex Parte Seizure Order in Counterfeiting Action in Canada" (1981) 71 T.M.R. 266 al 267-68. 
The plaintiff undertook to serve on the defendants a copy of the order and copies of the pleadings and materials filed by the plaintiff, and to provide security in the event of damages being sustained by the defendants in the execution of the order. The court ordered the defendants "by the person appearing to be in charge of the defendants' premises" to permit the plaintiff to enter the defendant's premises, to search for and remove any and all goods which appeared to be counterfeit and any documents which appeared to be related to such goods. The defendants were ordered to reveal, within twenty-four hours, the existence and whereabouts of any pertinent goods or documents under their care and control not on the premises. The court forbade each defendant to reveal anything about the order or, in fact, anything about this case, other than to his solicitor for the purposes of defending the action, and it restricted the number of persons who could enter the defendant's premises to a maximum of four, requiring at least one of the persons to have been instructed by a solicitor as to a proper method for executing the order. The court also enjoined the further importation, sale and distribution of counterfeit goods. The order was made effective for a period of approximately three weeks, but the defendants were permitted to move to dissolve the order at any time on twenty-four hours notice.

As was the case in England, it was left for a subsequent decision, Bardeau Ltd. v. Crown Food Service Equipment Ltd., ${ }^{32}$ to set out the prerequisites to obtaining such an order. Noting that it is ". . . a most exceptional remedy and should be approached with the greatest of caution" ${ }^{33}$ and that there was only one precedent in the jurisdiction, ${ }^{34}$ the Ontario High Court exercised its jurisdiction under Rule 372 (the equivalent to Alberta Rule 468) and its inherent jurisdiction in granting the order on the basis that the plaintiff (1) would undertake to indemnify the defendants for damages the latter may suffer as a result of the order; (2) would promise that their solicitor would serve the order and explain its meaning and effect to the defendants, and advise them of their right to obtain legal advice before disclosing the information required about the order; and (3) had presented a strong prima facie case that the defendants were possibly infringing on their intellectual property rights, that the defendants' conduct disclosed a total disregard for those rights and that there was a serious risk that evidence would be destroyed if not produced for the purpose of the projected action. ${ }^{35}$ The Court also recognized that the principles governing interim injunctions are separate from and inapplicable to motions like the one before it. ${ }^{36}$

The only appellate level Anton Piller case in Canada to date is Nintendo of America Inc. v. Coinex Video Games Inc., ${ }^{37}$ where the Federal Court of Appeal followed Lord Justice Ormrod's test in Anton Piller as well as the less onerous criteria in a subsequent English decision, Yousif v. Salama, ${ }^{38}$ which only required the plaintiff to show prima facie that evidence essential to his case was at risk. It is submitted that the latter approach was not as persuasive as that of Ormrod L.J. for three reasons. First, the Court in Nintendo was concerned with video game parts and the extensive damage to the plaintiff's operations by infringing parties flooding the market with cheaper imitations. However, the issue

32. Bardeau Lıd. v. Crown Food Service Equipment Lıd. (1982) 26 C.P.C. 297 (Ont.H.C.).

33. Id. at 299.

34. R.T.Z. Services Ltd. v. Stewart, unrep. December 12, 1980 (Ont.H.C.) per Saunders J.

35. Supran. 32 at $300,302$.

36. Id. at 302.

37. Nintendo of America Inc. v. Coinex Video Games Inc. (1982) 69 C.P.R. (2d) 122 (F.C.A.).

38. Yousifv. Salama [1980] 3 All E.R. 405 at 406, 408 (C.A.). 
in Yousif was whether the court had the discretion to issue an Anton Piller order to preserve documents not forming the subject matter of the action. Evidently, the Court saw fit to relax Lord Justice Ormrod's test to accommodate the greater ease with which accounting files could be removed or destroyed by the defendant; however, such would not be the case with a typical intellectual property pirate who mass produces infringing copies. Secondly, Yousif was an action to enforce a debt as opposed to an intellectual property right, and it can be argued that granting the order in every creditor's rights dispute would fly in the face of established judicial reluctance to grant it save in exceptional circumstances, terminally clog the courts and ultimately dilute the effectiveness of the order as a remedy by destroying its essential element of surprise. Finally, Nintendo was actually decided on the basis of the stricter Anton Piller test, so the remarks concerning the Yousif case were obiter dicta.

The next Anton Piller case before our courts, Chin-Can Communication Corp. v. Chinese Video Centre, ${ }^{39}$ returned to Lord Justice Ormrod's test, denying the relief requested on the ground that hearsay evidence and an unsupported statement that the plaintiff believed the order was the only way to recover the infringing materials did not meet the criteria of factual evidence of serious harm to the applicant, possession by the defendant or the possibility that the latter would destroy the relevant material before an inter partes application could be made. ${ }^{40}$ Although the court felt the ex parte application was unjustified, it did grant an interlocutory injunction to restrain the defendant from using or disposing of the impugned tapes. Not surprisingly, the tapes had disappeared by the time the order was served on the defendant. ${ }^{41}$.

The only other judicial traces of the Anton Piller order in Canada are two unreported decisions from the Federal Court ${ }^{42}$ and one from British Columbia, ${ }^{43}$ a pair of obiter references by the Ontario and Federal Courts of Appeal ${ }^{44}$ and an unpublished article by Mr. Justice Tallis of the Saskatchewan Court of Appeal. ${ }^{45}$

\section{EXISTING PROTECTION IN CANADA}

The plaintiff's frustrated claim in the Chin-Can case underscores the need for an effective remedy for the preservation and recovery of pirated materials in Canada. There is legal recourse available to the holder of an intellectual property right beyond that provided by the Federal Court Act and the various rules of court discussed above, but it has proven to be incomplete and inadequate.

39. Chin-Can Communication Corp. v. Chinese Video Centre (1983) 70 C.P.R. (2d) 184 (F.C.T.D.).

40. Id. at 187.

41. Supran. 5 at 44.

42. Sony v. Sunshine Import, unrep. November 8, 1982 (F.C.T.D.), No. T-8611-82 per Walsh J.; Midway Mfg. Co. v. Bernstein [1983] D.R.S. 53-778 (F.C.T.D.).

43. Alznner National Arch Supports Ltd. v. Michaluk, unrep. June 13, 1983 (B.C.S.C.), No. A831803 per Hinds J.

44. R. v. Kirkwood (1983) 42 O.R. (2d) 65 at 72 (Ont. C.A.); A.G. Canada v. Gould (1984) 42 C.R. (3d) 88 at 92 (F.C.A.).

45. C. Tallis, "Mareva Injunctions and Anton Piller Orders" (1984) C.I.A.J. Judicial Seminar on Remedies, pp. 41-49. 
The Copyright Act entitles a copyright holder to ". . . all such remedies by way of injunction, damages, accounts, and otherwise, as are or may be conferred by law for the infringement of a right" 46 and provides that he may recover possession of the infringing material or sue for its conversion. ${ }^{47}$ The court may order that the infringing copies or plates for making them be delivered up to the plaintiff, destroyed or otherwise dealt with at the court's discretion. ${ }^{48}$ Finally, summary conviction of fences are enumerated for various breaches of the Act and punished by fines ranging from $\$ 10$ for each infringing copy made for sale or hire ${ }^{49}$ to $\$ 500$ or a maximum sentence of four months imprisonment for altering the name of the author or title of a dramatic, operatic or musical work in order to perform it for profit. ${ }^{50}$ These provisions are unlikely to deter large-scale copyright violations and must be revised "to meet the challenges of the new environment . . ."51 and ". . . adequately reflect today's economic circumstances." ${ }_{52}$ The problem of inadequate copyright legislation dates back to the rampant unauthorized reproduction of sheet music in England around the turn of the century, and the fact that the latter is no longer as prevalent owes more to the declining popularity of singing around the parlour piano than to any copyright legislation..$^{53}$

The need for the Anton Piller order was recognized by a special English committee struck to consider the law on copyright and design when it rejected submissions from the British phonographic industry and the musical community calling for statutory search and seizure provisions. The committee noted the recent development of the Anton Piller practice and concluded that it of fered sufficient protection to copyright holders so as not to warrant recommending any further legislative provisions to such effect. ${ }^{54}$

The Industrial Design Act is even more disconcerting to potential plaintiffs. It prohibits the unauthorized use of a registered design without leave of the proprietor ${ }^{55}$ and prescribes maximum penalties of $\$ 120$ for publishing for sale or selling such a design ${ }^{56}$ and $\$ 30$ for false representations pertaining thereto, ${ }^{57}$ the fines being recoverable by the plaintiff on the defendant's summary conviction. ${ }^{58}$ Damages lie for a known imitation or application for sale purposes without the owner's consent, ${ }^{59}$ but

46. Copyright Act, R.S.C. 1970, c. C-30, s. 20(1).

47. Id., s. 21 .

48. Id. s. 25(3).

49. Id. s. 25(1)(a).

50. Id. s. 26(2).

51. Government of Canada, From Gutenberg to Telidon: A White Paper on Copyright (1984) 2.

52. Id. at 71 .

53. Copyright and Designs Law: Report of the Committee to Consider the Law on Copyright and Designs (1977) 182.

54. Id. at 183 .

55. Industrial Design Act, R.S.C. 1970, c. I-8, s. 11.

56. Id. s. 16(1).

57. Id. s. 17.

58. Id. s. 16(2).

59. Id. s. 15. 
not against a mere seller ${ }^{60}$ and only by the proprietor of the design. ${ }^{61}$ The Act does not provide for the granting of injunctive relief, so a plaintiff must resort to s. 20 of the Federal Court Act when his property rights are in danger. ${ }^{62}$ Although the Industrial Design Act does not mention the remedy of delivering up, it may be ordered as part of the inherent equitable jurisdiction of the court. ${ }^{63}$ Thus, a plaintiff seeking to preserve and seize suspected infringements on his design would be left to his provincial rules of court, the common law injunction or the risky remedy of self-help.

The Patent Act imposes liability for damages occasioned by an infringement ${ }^{64}$ and gives the court the discretion to make an order restraining a defendant from further use, manufacture or sale of the articles infringing on the plaintiff's patent, ${ }^{65}$ punishing deviations from such orders, ${ }^{66}$ providing for inspection or account ${ }^{67}$ and any other order generally concerning the proceedings. ${ }^{68}$ This allows a plaintiff to inspect an allegedly infringing machine prior to delivering his statement of claim if he has a bona fide belief that there is an infringement and he is unable to provide proper particulars thereof without an inspection. ${ }^{69} \mathrm{He}$ is also entitled to a permanent injunction, but he must elect either an account of profits from the sale or use of the patented invention or a payment of damages. ${ }^{70}$ These remedies are beneficial to a party seeking to protect his patent, but as no court has made such an inspection order on an ex parte basis, the need for immediate action "before the horse has bolted" is unsatisfied. Indeed, a plaintiff in one patent infringement action was denied an inspection order under s. 59(1)(b) of the Act and Federal Court Rule 471 because his application was made before the defendant had the chance to file a statement of defence, ask for particulars or object to the sufficiency of the plaintiff's pleading. ${ }^{71}$

The Trade Mark Act offers the strongest statutory protection of intellectual property in Canada. Violations of the Act are enforceable by any court order required by the circumstances, including relief by way of injunction or the recovery of damages or profits 72 and a prohibition on future imports likely to infringe on the Act. ${ }^{73}$ Also, the court may direct

60. Société Anonymev. Bruner(1976) 25 C.P.R. (2d) 153 at 154 (Que.C.A.).

61. Woolleyv. Broad [1892] 1 Q.B. 806 at 810.

62. Cimon Lid. v. Bench Made Furniture Corp. (1964) 48 C.P.R. 31 at 66 (Ex.Ct.).

63. Boosey v. Whight \& Co. (No. 2) (1899) 81 L.T. (N.S.) 265 at 266 (Ch.D.); Isaacs v. Fiddeman (1880) 42 L.T. (N.S.) 395 (Ch.D.).

64. Patent Act, R.S.C. 1970, c. P.4, s. 57(1).

65. Id. s. $59(1)(\mathrm{a})$.

66. Id.

67. Id. s. $59(1)(\mathrm{b})$.

68. Id. s. $59(1)$.

69. Smit \& Sons Lid. v. Fastcut Bits Lid. [1948] O.W.N. 478 at 479-80 (Ont.H.C.).

70. Feldstein v. McFarlane Gendron Mfg. Co. (1966) 34 Fox Pat. C. 113 at 118 (Ex.Ct.); Steel Co. v. Siraco Wire \& Nail Co. (No. 3)(1973) 11 C.P.R. (2d) 153 at 206 (F.C.T.D.).

71. Sealed Air Corp. v. Alros Products Ltd. (1980) 51 C.P.R. (2d) 69 at 70 (F.C.T.D.).

72. Trade Mark Act, R.S.C. 1970, c. T-10, s. 53.

73. Id. s. 52(4). 
the disposition of offending materials ${ }^{74}$ and grant an order for their interim custody pending the determination of their legality where a registered trade mark or name has been imported or is about to be distributed in Canada. ${ }^{75}$ The latter may be made with notice or ex parte and requires an undertaking for any damages by the plaintiff. ${ }^{76}$ This resembles the Anton Piller order but has only once been invoked ex parte. ${ }^{77}$ Perhaps the trend toward the new remedy will breathe life into that provision of the Act.

Other sections of the Trade Mark Act codify the common law action of passing of $\mathrm{f}^{78}$ and overlap with sundry offences enumerated in the Combines Investigation Act ${ }^{79}$ and the Criminal Code. ${ }^{80}$ Section 7(a) of the Trade Mark Act resembles s. 18 of the Combines Investigation Act in prohibiting false or misleading advertising. Sections 7 (c) and (d) duplicate s. 366 of the Code in forbidding the passing off of wares and services as well as forbidding falsely describing them. Although the Trade Mark Act does not penalize violations, the effect of s. 115 of the Code is to criminalize a wilful disobedience of ss. 7 (unfair competition), 9 (prohibited marks), and 10 and 11 (further prohibitions). ${ }^{81}$ Although s-ss. $7(b)^{82}$ and $(e)^{83}$ have been held ultra vires Parliament as not specifically relating to trade marks, and other subsections of the Act may follow suit, ${ }^{84}$ the Code offences stand. The only remedy under the forgery of trade marks and trade descriptions provisions in ss. 364 to 372 will be by criminal prosecution as opposed to private action. ${ }^{85}$ Sub-section $370(2)$ of the Code states that articles relating to any of those offences will be forfeited upon the conviction of the infringing party unless the court considers otherwise.

Apart from the above is the common law action of passing off, which is ". . . left to the chance of private redress ..." and is unconnected to any general regulatory scheme governing trade marks. ${ }^{86}$ Passing off consists of injurious conduct by a person that would mislead the public into believing that a connection exists between his wares, services or business and those of a competitor; the basis of the action is the defendant's misappropriating the plaintiff's reputation. ${ }^{87}$ The latter's remedies are similar to those available in an action for trade mark infringement: he

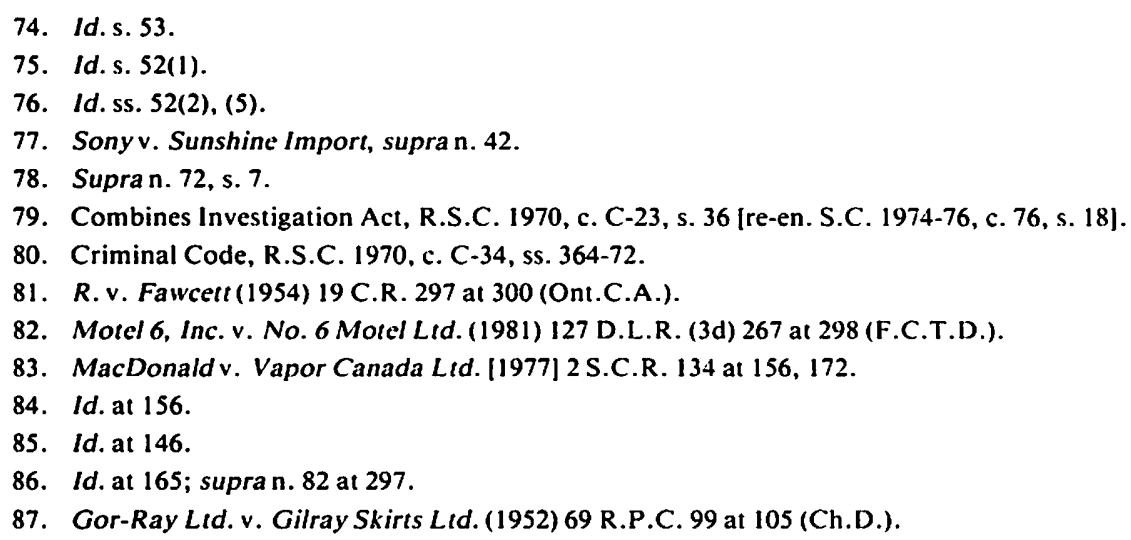


may obtain an injunction and damages ${ }^{88}$ combined with the delivery up $^{89}$ or destruction of all passed off material and an account of the defendant's resulting profits.

The Federal Court of Canada only has jurisdiction to hear a passing off claim if the right asserted is intra vires the federal legislative authority. ${ }^{90}$ Similarly, it has no jurisdiction over a common law action for unfair competition or for practice contrary to honest industrial or commercial usage in Canada unless the claim is somehow connected with the Trade Mark Act. ${ }^{91}$ The Court is further limited in that it can only grant an ex parte injunction for up to ten days. ${ }^{92}$ Although Rule 469 empowers the Court to issue ex parte interlocutory injunctions, ${ }^{93}$ it has never been used in connection with the Rules authorizing the inspection and seizure of infringing property. Although its orders are binding in every province, the Court may not be in a position to satisfy a plaintiff's need for immediate relief when it is not sitting near his judicial district. In any case, a breach of an intellectual property right conferred by common law or statute gives rise to an action in tort ${ }^{94}$ enforceable in the jurisdiction in which it is brought. A plaintiff may always resort to the traditional remedies at common law and equity, but it was the deficiencies of both that necessitated the Anton Piller order.

Thus, the limited effect of the common law and statutory remedies for the violation of an intellectual property right in Canada emphasizes the need for the Anton Piller order as an immediate method of rectifying suspected violations of that right. Most of the legislative provisions contain very minimal deterrents and are rarely invoked, and with the exception of s. 52(5) of the Trade Mark Act, none of them recognize that the pirate's code of conduct does not include honest compliance with the injunction or delivery up order with which he is served. Consequently, our law is missing an important tool in its quest ". . . to secure a fair return for ... creative labour ... [and] to stimulate ... creativity for the general public good." 95 This is demonstrated by S.D.R.M. v. Trans World Record Corp. ${ }^{96}$ where the plaintiff sought an order directing the seizure of tapes, records and matrices used to produce them and ordering that they remain in the court's custody until final judgment. Both divisions of the Federal Court dismissed the application on the basis that the balance of convenience weighed against it, adding that Rule 470 could not be used to give "special effect" to the plaintiff's right to take proceedings to recover possession of the property under the Copyright Act.

88. Vennootschap v. Townend \& Sons Ltd. [1979] 3 W.L.R. 68 (H.L.).

89. Bow City Delivery Lid. v. Independent Cab Co. (1972) 33 D.L.R. (3d) 729 (Alta. S.C. T.D.).

90. Supran. 82.

91. Benjamin Dist. Lıd. v. Les distributions Eclair Lıée. [1975] F.C. 250 at 253 (F.C.T.D.).

92. S.A.D.A. Ltee. v. College Edouard-Montpetit (1980) 58 C.P.R. (2d) 119 (F.C.A.).

93. Supran. 23.

94. Blue Crest Music Inc. v. Compo Co. [1980] I S.C.R. 357; affg. (1976) 14 N.R. 416 at 418 (F.C.A.); Featherv. The Queen(1865) 6 B.\&S. 257 at 297, 122 E.R. 1191 at 1206 (K.B.).

95. Twentieth Century Music Corp. v. Aiken (1975) 422 U.S. 151 at 156 (U.S.S.C.); Sony Corp. v. Universal City Studios (1984) 104 S.Ct. 774 at 783 (U.S.S.C.).

96. S.D.R.M. v. Trans World Record Corp. (1975) 39 C.P.R. (2d) 66 (F.C.A.). 
Surely the need for immediate and effective relief is fundamental to the protection of one's intellectual property rights. It is submitted that this gap in the law is met by the Anton Piller order, the efficacy of which does not stem from giving "special effect" to a particular section in a statute but from its nature as an exceptional form of injunctive relief applicable to all cases meeting the prescribed requirements.

\section{FUTURE ANTON PILLER ISSUES IN CANADA}

As there have been only half a dozen Anton Piller orders granted in Canada as of the end of 1984 , it would be prudent to look to cases before the courts in England, where the recent trend has been to grant them ". . . almost as a matter of course."'97 In addition to the practical considerations to be discussed below, English courts have dealt with five important issues rising out of the Anton Piller order that are likely to come before our courts in the future. There is also the Canadian Charter of Rights and Freedoms to be reckoned with.

\section{A. REQUIREMENTS OF DESCRIPTION AND DISCLOSURE}

It is essential that an applicant for an ex parte order fully disclose all matters within his knowledge that are relevant to the application whether or not they support his case. ${ }^{98}$ The failure to do so, whether negligent or deliberate, will result in the order being discharged without an investigation of its merits. ${ }^{99}$ This is because: ${ }^{100}$

As time goes on and the granting of Anton Piller orders becomes more and more frequent, there is a tendancy to forget how serious an intervention they are in the privacy and rights of defendants. One is also inclined to forget the stringency of the requirements as laid down by the Court of Appeal. In my judgment the rule of full disclosure to the court is almost more important in the Anton Piller cases than in other ex parte applications. Since Anton Piller orders give compulsory rights of inspection, once those inspections have taken place the information procured from it is in the hands of the other side and the situation is irreversible. I therefore think it is very important indeed that in making applications it should be in the forefront of everybody's mind that the court must be fully informed of all facts that are relevant to the weighing operation which the court has to make in deciding whether or not to grant the order.

Ancillary to the requirement of putting all matters before the court is the judge's duty to ignore information presented by the applicant that cannot ultimately be disclosed to the defendant because of its confidentiality; the court may only consider issues based on evidence known to both parties. ${ }^{101}$

Not every non-disclosure will discharge the order. For example, an applicant's failure to mention that it had done business with the defendant in the past, that one party had allegedly stolen the other's secretary and that its premises were mortgaged when it was described as freehold pro-

97. Sega Enterprises Ltd. v. Alca Electronics [1982] F.S.R. 516 at 523 (C.A.); Protector Alarms Lıd. v. Maxim Alarms Ltd., supra n. 17 at 443; Ex parte Island Records Ltd., supra n. 17 at 828.

98. W.E.A. Records Ltd. v. Visions Channel 4 Lid. [1983] 2 All E.R. 589 at 593 (C.A.).

99. Thermax Lid. v. Schott Ind. Glass Ltd., supra n. 16 at 294; Midway Mfg. Co. v. Bernstein, supra n. 42.

100. Id. at 298.

101. Supra n. 98 at 593-94. 
perty are insufficient to vitiate an order. ${ }^{102}$ However, an applicant's nondisclosure of a previous unsuccessful attempt to inspect the defendant's premises and the fact that on those premises were confidential articles unrelated to the application are material and should have been before the judge hearing the application. ${ }^{103}$ This is because the presence of technological or other trade secrets on the defendant's premises is of paramount significance in balancing the conflicting interests of justice to the plaintiff and preventing possible harm to the defendant by allowing its trade secrets to be disclosed. ${ }^{104}$ Another misrepresentation which could set aside an Anton Piller order is an applicant's assertion that the defendant was a sham corporation controlled by three of the applicant's former employees against whom proceedings were being taken, when it was actually owned and operated by a company ultimately controlled by a large international foundation. ${ }^{105}$ It is highly relevant for a judge to consider the directorship of a corporate defendant when assessing whether it is likely to act in an unlawful manner (the third branch of the test in Anton Piller), the presumption being that a large industrial group organizes its affairs honestly and competently. ${ }^{106}$

Since the order requires precision to be effective, a court will rarely issue one describing the premises to be searched in general terms. Thus, a request for an order authorizing the plaintiff to search particular buildings and "any other premises under the control of the defendant" will only be granted in special circumstances ${ }^{107}$ even though the plaintiff's motive (in this instance, a concern over storage sheds and annexes not covered by the defendant's street address) may seem innocuous enough. The order should clearly delineate the number of parties permitted to enter the defendant's premises, the objects of the search, the specific functions to be performed during the search (such as taking photographs) and reasonable hours during which the order may be executed. One must bear in mind that: ${ }^{108}$

... any room for argument as to the precise scope and effect of the order must increase the not negligible risk of breach of peace when orders of this kind come to be executed.

\section{B. PLAINTIFF'S USE OF THE SEIZED PROPERTY}

Property held by the applicant's solicitor under an Anton Piller order is subject to the same implied undertaking covering documents disclosed on discovery. Accordingly, the applicant's solicitor is not entitled to allow the property to be used for any collateral or ulterior purpose without leave of the court. ${ }^{109}$ Leave to inspect the property will be granted to permit an investigation instituted by an administrative

102. Gallery Cosmetics Ltd. v. Number I [1981] F.S.R: 556 (Ch.D.).

103. Thermax Ltd. v. Schott Ind. Glass Ltd., supra n. 16 at 297-98.

104. Id. at 297.

105. Id.

106. Id.

107. Protector Alarms Ltd. v. Maxim Alarms Ltd., supra n. 17 at 444.

108. Id. at 446 .

109. Customs \& Excise Commissioners v. A.E. Hamlin \& Co. [1983] 3 All E.R. 654 at 661 (Ch.D.). 
tribunal under its statutory powers. ${ }^{110}$ This raises the question of whether information obtained pursuant to an Anton Piller order may be used to institute or support proceedings against the defendant or other parties.

In a recent case before the Chancery Division, the plaintiff sought leave to inform the police of occurrences during the search and present them with documents and infringing copies that were found. The Court refused leave, holding that it might properly allow such documents to be released to the police in certain circumstances, but the mere fact that they may establish the commission of a criminal of fence was insufficient to justify a departure from the general rule that documents seized under an Anton Piller order should only be used for the purpose of proceedings in which the order was obtained. ${ }^{111}$ However, there is an exception to the rule: 112

One of the main purposes of the Anton Piller order is to enable the plaintiff to get information from the defendant for the very purpose of using such information not against the defendant but against third parties. Therefore, it seems that information obtained under an Anton Piller order can be used for the purposes of pursuing claims against third parties implicated in the same wrongful handling of the same infringing goods. . . I I do not consider that there is any limit which prevents information obtained pursuant to an Anton Piller order being used to institute or support criminal proceedings against third parties.

It would seem that this could be extended to civil proceedings against third parties. In a subsequent case, ${ }^{113}$ the plaintiff obtained an Anton Piller order and at the inter partes hearing requested, inter alia, that the defendant disclose the names and addresses of their hirers. The defendant objected on the ground that such a disclosure would lead to the plaintiff bringing actions against the hirers and result in a loss of goodwill to the defendant. The Court of Appeal held that the trial judge should have refused to exercise his jurisdiction to order the disclosure because that information would not assist the plaintiff in its action for breach of copyright. The Court stated that the trial judge ought to have considered whether the third parties' names and addresses were relevant to the issues at trial since the plaintiff would be able to use the information to the defendant's prejudice even if the former lost at trial. ${ }^{114} \mathrm{Ac}-$ cordingly, the power to order disclosure should not be exercised unless the court is reasonably satisfied that the plaintiff will suffer irreparable damage if the action is delayed. ${ }^{115}$ An order that the defendant disclose the names and addresses of the suppliers of the infringing materials in its possession has been upheld as a legitimate extension of the Anton Piller principle. ${ }^{116}$

Disclosure may be dealt with by the parties themselves. In Sony v. Time Electronics, ${ }^{117}$ the plaintiff obtained an Anton Piller order against

110. Id.

111. General Nutrition Ltd.v. Pattni [1984] F.S.R. 403 (Ch.D.).

112. Sony Corp. v. Amand [1981] F.S.R. 398 at 402 (Ch.D.); Rank Film Dist. Ltd. v. Video Information Centre [1981] 2 All E.R. 76 (H.L.); affg. [1980] 2 All E.R. 273 at 292 (C.A.).

113. Sega Enterprises Ltd. v. Alca Electronics, supra n. 97.

114. Id. at 521 .

115. Id. at 523 .

116. E.M.I. Ltd.v. Sarwar[1977] F.S.R. 146 at 147 (C.A.).

117. Sony Corp. v. Time Electronics [1981] F.S.R. 333 (Ch.D.). 
the defendants for passing off its "Walkman" tape players, but gave a cross-undertaking not to use any information obtained while executing the order for purposes other than civil proceedings related to the subject matter of the action. While executing the order, the plaintiff's solicitor noticed what he suspected to be counterfeit Sony tapes. He dispatched one of his office clerks to the defendant's store to purchase a tape, which proved to be an inferior product with the Sony name on it. The Court granted the plaintiff's application for another Anton Piller order for the inpugned tapes because it was founded on the test purchase as opposed to something that the Court had previously ordered to be disclosed. The observation by the plaintiff's solicitor was held to be collateral to the execution of the earlier order and not dependant on it for its justification. ${ }^{118}$ In another case, the Court granted an order containing an undertaking by the plaintiff not to use evidence secured thereunder in criminal proceedings. ${ }^{119}$ However, it was noted obiter that the overriding importance of the court's enforcing its orders required such evidence to be admitted in contempt proceedings, notwithstanding the undertaking. ${ }^{120}$

\section{CONTEMPT OF COURT}

In the Anton Piller case, both Lord Denning and Ormrod L.J. declared that it was always open for a defendant faced with an order at this doorstep to refuse to comply with it, albeit at the risk of further proceedings for contempt of court. ${ }^{121}$ The first question to confront Canadian courts on this issue concerns the outcome of such proceedings where a defendant refused to comply with the order and the order was subsequently discharged on an irregularity. In a recent English case, Goulding J. made the following point: ${ }^{122}$

... in the absence of authority and if $I$ were free to look at the matter on first principles, I would have thought that the subsequent discharge of an order as having been irregularly obtained would not in logic and principle affect the disobedient party's liability to penalties for contempt.

...

It seems to me that the system of administering justice would break down if the subjects were entitled to apply their own or their advisers' ideas to the possibilities of subsequently setting aside an order and to disobey on the strength of such private judgment and then, if the judgment turned out not to have been right, be free from all penalty.

It should be noted that the learned judge was referring to orders made within the court's jurisdiction (as in the case before him, where the plaintiff's affidavit failed to disclose material facts) as opposed to orders which are void $a b$ initio. ${ }^{123}$ It follows that although the defendant may only escape contempt proceedings if the order was made without jurisdiction, the court will always consider the circumstances in sentencing. In

118. Id. at 335.

119. Chanel Ltd. v. F.G.M. Cosmetics [1981] F.S.R. 471 (Ch.D.).

120. Id. at 477.

121. Supra n. 4 at $282-84$.

122. Wardle Fabrics Ltd. v. Myristics Ltd. [1984] F.S.R. 263 at 271-73 (Ch.D.); a contrary view was expressed in obiter in Hallmark Cards Inc. v. Image Arts Ltd., supra n. 17 at 152.

123. Id. at 266. 
the above case, Goulding J. considered the absence of violent behavior and waived the customary penalty of a small fine, directing the defendants to pay the plaintiff's costs of the contempt application on an indemnity basis. ${ }^{124} \mathrm{~A}$ similar result occurred in an earlier case where the defendant's non-compliance was also deliberate, but he was out of the city when the plaintiff turned up with the order at his business premises. The Court noted that the contempt was not as bad as the facts suggested. ${ }^{125}$ The Chancery Division continued this flexible approach in dismissing an application to commit a defendant for violating an Anton Piller order on the ground that the breach was trivial, based largely on advice he had received, and involuntary, the defendant having been "... under the normal confusion and distress consequent upon such an order."126 Thus, the apparent harshness of punishing a non-complying defendant may be mitigated on the proper facts.

\section{DISCHARGING OR APPEALING THE ORDER}

As the Anton Piller order begins to gain favour on this side of the Atlantic, our courts will be called upon to assess claims by defendants seeking to discharge them. The English 1 ule is that an order may not be discharged once the defendant has complied with it because it has been spent and " $[t]$ he courts are concerned with the administration of justice, not with playing a game of snakes and ladders." 127 In such a case, the defendant's proper course of action is to proceed against the plaintiff after the trial on the undertaking as to damages given by the latter when the order was originally granted. ${ }^{128}$

As an ex parte order is by its nature made on an interim basis, it is expected to be varied or discharged by the judge granting it or by another court of competent jurisdiction in light of subsequent evidence and argument. ${ }^{129}$ It would therefore be wrong for a court to suspend the operation of an order on an ex parte application by the defendant. ${ }^{130}$ It is only after such an application is properly brought, heard and adjudicated that a defendant could seek relief in an appellate court; otherwise, the appeal will be dismissed as an abuse of process. ${ }^{131}$

It has been held that the defendant's failure to exercise his right to apply to discharge an Anton Piller order does not preclude his obtaining injunctive relief, although the situation may well be different with respect to varying the directions for inspection. ${ }^{132}$ Presumably, this is because the damage he suffers may be irreversible if he delays long enough for the plaintiff to act on the information revealed by the inspection. In any case, the discretionary nature of both the order and its terms trigger the

124. Id. at 276.

125. Chanel Ltd. v. 3 Pears Wholesale Cash \& Carry Co. [1979] F.S.R. 393 at 394 (Ch.D.).

126. H.P.S.I.v. Thomas [1983] C.L.Y. 2855 (Q.B.).

127. W.E.A. Records Ltd. v. Visions Channel 4 Ltd., supran. 98 at 594 per Donaldson M.R.

128. Id.

129. Id. at 593.

130. Hallmark Cards Inc. v. Image Arts Ltd., supra n. 17 at 152.

131. Supran. 98 at 593-94.

132. Bestworth Ltd. v. Wearwell Ltd. [1979] F.S.R. 320 at 321 (Ch.D.). 
rules of equity, ${ }^{133}$ including the doctrine of laches, ${ }^{134}$ all of which apply to both parties.

It is always open for the defendant to counterclaim against the plaintiff in trespass on the basis that the latter exceeded the scope of the order, but the counterclaim will be struck out if it raises matters unconnected to the question of liability for violating the plaintiff's intellectual property rights (in which case it should be considered separately, if at all) or if the defendant did not raise the trespass prior to the counterclaim. ${ }^{135}$ Furthermore, no counterclaim lies in contract for the plaintiff's breach of a cross-undertaking because that is a matter for the court to enforce. ${ }^{136}$ As property seized under a subsequently discharged warrant will be returned to the defendant under the court's inherent jurisdiction to discharge the warrant, ${ }^{137}$ the same remedy should be granted in cases of discharged Anton Piller orders.

\section{E. SELF-INCRIMINATION}

The court may refuse to grant an Anton Piller order if the disclosure requirement might cause the defendant to incriminate himself. The common law rule in Canada is that depositions of a witness are inadmissible in subsequent criminal proceedings against him without his consent. ${ }^{138}$ This has been codified in the federal and provincial Evidence Acts ${ }^{139}$ as well as the Charter of Rights and Freedoms. ${ }^{140}$ However, a defendant answering the door when a plaintiff serves him with an Anton Piller order may not be protected by the above legislation since he is not a witness at that point and certain statements may not have been deposed at the civil proceeding against him. In the Chin-Can case, the Federal Court recognized: ${ }^{141}$

... the very serious question of self-incrimination having regard to the penal provisions of ss. 25 and 26 of the Copyright Act ... [S]ince the amendments to our constitution have now been proclaimed in force, a valid argument might well be made against any such general disclosure order being granted in the future, even where a general right to search by "Anton Piller" order is being allowed.

In the Rank Film case, ${ }^{142}$ the House of Lords discharged the provisions of an Anton Piller order compelling the defendant to disclose the names and addresses of its suppliers and customers on the ground that it could be exposed to the common law offence of conspiracy to defraud. The

133. Bardeau Ltd. v. Crown Food Service Equipment Ltd., supran. 32 at 308.

134. E.M.I. Ltd. v. Pandit, supra n. 3 at 421; Wilmot Breeder Ltd. v. Woodcock [1981] F.S.R. 15 at 16 (Ch.D.).

135. Fletcher Sutcliffe Wild Ltd.v. Burch [1982] F.S.R. 64 at 71 (Ch.D.).

136. Id. at 70.

137. R. v. Bergeron (1977) 14 N.R. 83 at 84 (S.C.C.); Re Adler and the Queen (1977) 37 C.C.C. (2d) 234 at 251-52 (Alta.T.D.); Re Gillis and the Queen (1982) I C.C.C. (3d) 545 at 556 (Que.S.C.).

138. R. v. Coote (1873) L.R. 4 P.C. 599 at 607 (J.C.P.C.).

139. For example: Canada Evidence Act, R.S.C. 1970, c. E-10, s. 5(2); Alberta Evidence Act, R.S.A. 1980, c. A-21, s. 6(2); Ontario Evidence Act, R.S.O. 1980, c. 145, s. 9(2); British Columbia Evidence Act, R.S.B.C. 1979, c. 116, s. 4(2).

140. Constitution Act, 1982, Part I, Schedule B, s. 13.

141. Chin-Can Communication Corp. v. Chinese Video Centre, supran. 39 at 189.

142. Rank Film Dist. Ltd. v. Video Information Centre, supra n. 112. 
Lords did not seem concerned about the defendant facing the considerably less severe fine of $£ 50$ under the Copyright Act 1956. ${ }^{143}$ This is where the English cases cease to be helpful on this point in this jurisdiction because the English Parliament, acting on Lord Russell's suggestion in Rank Film, ${ }^{144}$ enacted legislation withdrawing the privilege against non-disclosure in intellectual property cases while retaining the defendant's right not to have the disclosures admitted in subsequent proceedings ${ }^{145}$ in respect of any offence revealed on the facts. ${ }^{146}$ Thus, the principle in Rank Film applies in Canada although our statutory offences and penalties are different. It is submitted that the English legislation is the preferable approach because it cures what Lord Wilberforce pointed out to be the injustice resulting from the strength of the defendant's privilege being directly proportional to the apparent criminality of his infringement on the plaintiff's rights. ${ }^{147}$ This conclusion is reinforced by the fact that large-scale pirates will probably risk the relatively minor penalty provisions in Canadian intellectual property legislation as allowable business risks.

\section{F. POINTS OF PRACTICE}

As the immediate concern of a party seeking an Anton Piller order is confidentiality, he will obviously apply ex parte. However, if his application is ultimately dismissed, he may find it necessary to provide an appellate court with reasons for hearing his application in camera. The English Court of Appeal formulated a suitable arrangement whereby the applicant's counsel should hand the registrar of the Court a signed, written statement indicating his personal, professional belief (as distinct from that of his client) that the preliminary application for an appeal against the ex parte dismissal of the application should be heard in camera. ${ }^{148}$ This allows the Court to decide whether it will hear the appeal application in camera or in open court. This is a crucial step for the applicant because the latter result may emasculate his order even if it is ultimately granted since, as Templeman J. originally put it, "the horse will rapidly leave the stable" if the defendant receives notice of the application. ${ }^{149}$ Such was the undesirable consequence in the Chin-Can case. Moreover, the Court of Appeal has held that evidence tendered at an Anton Piller application is admissible even if the order ought not to have been granted. ${ }^{150}$ However, this does not strictly apply in Canada, where the Charter of Rights and Freedoms gives courts the power to exclude evidence in a Charter application where its admission would bring the administration of justice into disrepute ${ }^{151}$ and possibly also where the court deems it just

143. Copyright Act 1956 (U.K.), c. 74, s. 21.

144. Supran. 112 at 86.

145. Supreme Court Act 1981 (U.K.), c. 54, s. 72.

146. Universal Studios Inc. v. Hubbard [1984] ] All E.R. 661 at 664 (C.A.).

147. Supran. 112 at 79.

148. Practice Note [1982] 3 All E.R. 924 (C.A.).

149. E.M.I. Ltd. v. Pandit, supran. 3 at 421.

150. Helliwell v. Piggott-Sims [1980] F.S.R. 356 (C.A.).

151. Supran. 140, s. 24(2). 
and appropriate in the circumstances, ${ }^{152}$ although the latter is under debate. ${ }^{153}$ In any event, these provisions will only assist a defendant in an Anton Piller case if he can show a violation of one of the rights guaranteed under the Charter. The effect of this will be explored further below.

As Anton Piller applications begin to multiply, courts will be quick to take measures against overzealous plaintiffs by awarding costs against them. ${ }^{154}$ Thus, a plaintiff's solicitor must take great care in composing the application and ensure that the parties executing the order act within its scope. Failure to do so may seriously jeopardize the client's position as well as expose the solicitor to liability. Other considerations confronting the solicitor are the logistical problems in serving different defendants in different cities or time zones, the nature and portability of the material being seized, recording the events during the search (bearing the laws of evidence in mind) and the possibility of retaining a bailiff by a court order directing him to effect service and keep the peace. ${ }^{155}$ In that regard, it has been held that it is reasonable and common practice to inform the police so that a uniformed of ficer could remain outside the defendant's premises to prevent any imminent breaches of the peace; however, the plaintiff's notifying the police that the defendant was in possession of illegal materials and then permitting them to raid the defendant's premises during the execution of an Anton Piller order is undesirable because the two entries should not appear to be connected. ${ }^{156}$ Furthermore, it would be prudent for the plaintiff's solicitor to instruct the parties executing this order to be prepared to give affidavits regarding such execution since solicitors are not allowed to swear affidavits on matters material to proceedings in which they act. ${ }^{157}$ Also the court must be informed of the allegations made by the plaintiff in an application for injunctive relief; a plaintiff may not use an Anton Piller order as a research expedition for his statement of claim. ${ }^{158}$ Finally, the order will almost always be restricted to the jurisdiction in which it is obtained, ${ }^{159}$ although courts have the power to grant an order to inspect premises outside the jurisdiction where there is an equity such as fraud between the parties, and a defendant is in the jurisdiction. ${ }^{160}$

152. Id. s. 24(1).

153. R. v. Therens (1983) 33 C.R. (3d) 204 at 225 (Sask.C.A.); R. v. Wright (1983) 51 A.R. 124 at 131 (Alta. Q.B.) [affirmative view]; R. v. Simmons (1984) 45 O.R. (2d) 609 at 635 (Ont.C.A.) [negative view].

154. Systematica v. London Computer Centre Ltd. [1983] F.S.R. 313 (Ch.D.).

155. Cohen, supra n. 31 at 270-72.

156. I.T.C. Film Dist. v. Video Exchange Lid. (No. 2)(1982) 126 Sol.J. 672 (C.A.).

157. Canadian Bar Association Code of Professional Conduct (1974) Ch. VIII. Comm. 3; Lex Tex Canada Ltd. v. Duratex Inc. (1979) 13 C.P.C. 153 at 154 (F.C.T.D.); Kennett v. Gill (1969) 71 W.W.R. I at 3, 4 (Alta.A.D.); Imperial Oilv. Grabarchuk (1974) 3 O.R. (2d) 783 at 784 (Ont.C.A.); Pioneerv. Alberta Lumber [1923] 3 W.W.R. 1098 at 1099 (B.C.C.A.).

158. Hytrac Conveyors v. Conveyors International [1982] 3 All E.R. 415 at 418 (C.A.).

159. Protector Alarms Ltd. v. Maxim Alarms Ltd., supra n. 17 at 446.

160. Cook Industrial Corp. v. Galliher [1979] Ch. 439 at 443-44. 


\section{G. CHARTER OF RIGHTS AND FREEDOMS}

The acceptance of the Anton Piller order in this country raises the spectre of the Canadian Charter of Rights and Freedoms, which is part of the supreme law of Canada. ${ }^{161}$ The question of whether the Charter applies to private parties is yet to be conclusively resolved. One must begin with s. 32(1), which states that "[t]his Charter applies (a) to the Parliament and government of Canada in respect of all matters within the authority of Parliament ... and (b) to the legislature and government of each province in respect of all matters within the authority of the legislature of each province." The section was probably intended to ensure that the Charter applies to governments, as both the common law and the various Interpretation Acts declare that no enactment binds the Crown unless it expressly says so. ${ }^{162}$ Section 32 essentially states that anyone exercising statutory authority is bound by the Charter. This clearly covers administrative action because ". . . the Constitution would be mocked by substituting administrative for legislative interference."163 The same can be said for servants of the Crown attempting to assert the latter's rights or conduct investigations by way of an Anton Piller order.

There is a further argument that the rights guaranteed in the Charter should not be denied merely because it is not the government or one of its agents that is acting, ${ }^{164}$ but the better view appears to be that the Charter applies to the relationship between individuals and governments but not private individuals inter se ${ }^{165}$ since that would create a new field of civil liability better left to provincial human rights commissions, boards of inquiry ${ }^{166}$ or the traditional litigation process. This is reinforced by the recent decision of the Supreme Court of Canada, Hunter v. Southam Inc., ${ }^{167}$ where Chief Justice Dickson stated that the Charter " . . . is intended to constrain governmental action inconsistent with those rights and freedoms."

Nevertheless, the Charter can be argued to apply to the terms of an Anton Piller order on the ground that the court, a creature of statute, ${ }^{168}$ was exercising statutory authority in issuing the order. All judges may be said to fall "under the authority of Parliament" within s. 32(1)(a) of the Charter by virtue of their appointment under the Judges Act. ${ }^{169}$ There is

161. Constitution Act, 1982, s. 52(1).

162. For example: Interpretation Act, R.S.C. 1970, c. 1.23, s. 16; Interpretation Act, R.S.A. 1980, c. 1-7, s. 14; Interpretation Act, R.S.O. 1980, c. 219, s. 11; Interpretation Act, R.S.B.C. 1979 , c. 206, s. $14(1)$.

163. James v. Cowan [1932] A.C. 542 at 558 (J.C.P.C.); see also Re McCutcheon (1982) 147 D.L.R. (3d) 193 at 203 (Ont.H.C.).

164. M. Manning, Rights, Freedoms and the Courts (1983) 121.

165. F. Jordan, Senior Counsel to the Department of Justice, in the Proceedings of the Special Joint Committee on the Constitution of Canada, First Session, 32d Parl. 1980-81, January 30, 1981 at 49:47; the contrary view was taken in obiter in R.v. G.B. [1983] 3 W.W.R. 141 at 146 (Alta.Q.B.).

166. A. McLellan \& B. Elman, "Enforcement of the Canadian Charter of Rights and Freedoms: An Analysis of Section 24" (1983) 21 Alta.L.Rev. 205 at 223.

167. Hunterv. Southam Inc. (1984) 14 C.C.C. (3d) 97 at 106 (S.C.C.).

168. Federal Court Act, supra n. 19; e.g. Court of Appeal Act, R.S.A. 1980, c. C-28; Court of Queen's Bench Act, R.S.A. 1980, c. C-29.

169. Judges Act, R.S.C. 1970, c. J-1. 
considerable American authority to the effect that the state, in lending its support to private action, clothes it with the character of a state action and thereby extends the constitutional prohibition to the act of the private citizen. ${ }^{170}$ While such a prohibition would only extend to acts of the plaintiff that are consistent with the terms of his Anton Piller order, the order itself could be challenged as authorizing an unreasonable search and seizure contrary to s. 8 of the Charter, or perhaps even a violation of the defendant's security of the person contrary to fundamental justice principles as guaranteed under s. 7 .

The right to be secure from unreasonable searches and seizures may assist a defendant faced with an Anton Piller order because it affords wider protection than the common law trespass action against an entry into his premises which exceeds the legal authority to do so. ${ }^{171}$ In the Southam case, the Supreme Court held that: ${ }^{172}$

\footnotetext{
In cases like the present, reasonable and probable grounds, established upon oath, to believe that an of fence has been committed and that there is evidence to be found at the place of the search, constitutes the minimum standard consistent with s. 8 of the Charter for authorizing a search and seizure.
}

It is submitted that the above test should apply to cases where an Anton Piller order is sought to relieve against the infringement of an intellectual property right. Other circumstances that have been held to violate the reasonableness requirement which may also apply to Anton Piller situations are: the applicant's failure to express his belief that the items referred to in the judicial order afford evidence of the defendant's alleged misconduct; his honest belief without supporting evidence; his improper treatment of persons or objects found on the searched premises, and the defendant's exceeding the scope of the authorized search and seizure. ${ }^{173}$ On the latter point, pre-Charter cases decided under the seizure provisions in the Criminal Code ${ }^{174}$ have held that a search warrant cannot be used as a blanket endorsement to search and seize at will. ${ }^{175}$ This is consistent with the requirement of precision in composing an application for an Anton Piller order.

Although a defendant would have little difficulty in establishing that the plaintiff's entry, inspection and removal of infringing articles constituted a search and seizure for the purposes of s. 8 of the Charter, there is some debate as to whether a court order compelling him to produce documents (and by analogy, to disclose names and addresses of third parties and other infringing material) amounts to a seizure. The Alberta Court of Appeal has answered this question in the affirmative ${ }^{176}$ but the

170. Manning, supra n. 164 at 124; Marsh v. Alabama (1946) 226 U.S. 501 at 508-509 (U.S.S.C.); Pennsylvania v. Bd. of Directors of City Trusts (1956) 353 U.S. 230 at 231 (U.S.S.C.); Steele v. Louisville \& Nashville R.R. Co. (1944) 323 U.S. 192 at 202 (U.S.S.C.).

171. Supran. 167 at 107.

172. Id. at 115 .

173. Manning, supran. 164 at 121 .

174. Criminal Code, supra n. 80 , ss. $443,445$.

175. R. v. Purdy (1972) 4 N.B.R. (2d) 548 at 558 (N.B.C.A.); Shumiatcherv. A.G. Sask. (1960) 129 C.C.C. 270 at 272 (Sask.Q.B.).

176. Alta. Human Rights Commission v. Alta. Blue Cross Plan [1983] 6 W.W.R. 758 at 763 (Alta. C.A.). 
Federal Court of Appeal took the opposite view. ${ }^{177}$ Even if it was a seizure, it would probably be considered a reasonable limit justifiable under s. 1 of the Charter since it is a rational means of achieving a rational object, ${ }^{178}$ namely the protection of individuals and the public interest against increasingly sophisticated intellectual property pirates.

Another s. 8 concern is the plain view doctrine, which permits a police of ficer acting pursuant to a search warrant to seize incriminating material unnamed in the warrant but discovered in the course of its execution ${ }^{179}$ and reasonably believed to be useful as evidence. ${ }^{180}$ Since this doctrine has been accepted in Canada and held not to violate s. $8,{ }^{181}$ it is unlikely that a defendant could discharge an Anton Piller order authorizing the seizure of property not specifically named in the order as unconstitutional. This problem would not arise if orders were framed in terms wide enough to contemplate all forms of infringement of all intellectual property rights the plaintiff may have against the defendant, but the precision requirements of the order and s. 8 preclude an omnibus application tantamount to the proverbial fishing expedition. The most practical solution available to plaintiffs coming across infringing articles not covered by the order would be to apply for another order for those articles as in Sony Corp. v. Time Electronics. ${ }^{182}$

An unreasonable search and seizure is by definition precluded from being justified as a reasonable limit under $\mathrm{s} .1$ of the Charter ${ }^{183}$ The only remedy available against a plaintiff in an Anton Piller case under s. 24(1) of the Charter or the court's inherent jurisdiction is the return of the unlawfully seized material. ${ }^{184}$ Apart from $\mathrm{s}$. 8, there are three other provisions in the Charter of possible relevance to an Anton Piller action. The defendant may also seek relief under s. 7, which guarantees, inter alia, the right not to be deprived of personal security except in accordance with the principles of fundamental justice. It is unlikely that the ex parte nature of an Anton Piller order would be held to violate fundamental justice principles even if the defendant's security of the person could be said to be violated, given the entrenchment of ex parte applications in our legal system and the mischief they were designed to cure, not to mention s. 1 of the Charter. The application of s. 7 and the question of whether it includes a right to privacy are outside the scope of this paper. However, it may be said that it of fers wider protection against self-incrimination than ss. 11 (c) or 13 of the Charter, as such protection is ". . . deeply rooted in

177. Director of Investigation and Research v. Ziegler (1984) 51 N.R. 1 at 12 (F.C.A.); also see Re Belgona Tpt. Ltd. (1984) 47 O.R. (2d) 309 at 311-12 (Ont.Div.Ct.).

178. Reich v. College of Physicians \& Surgeons (No. 2) (1984) 53 A.R. 325 at 335 (Alta.Q.B.).

179. Coolidgev. New Hampshire (1971) 403 U.S. 443 at 466 (U.S.S.C.).

180 Texas v. Brown(1983) 103 S.Ct. 1535 at 1542 (U.S.S.C.).

181. Re Regina and Shea (1982) 142 D.L.R. (3d) 419 at 424 (Ont.H.C.); R. v. Longtin (1983) 147 D.L.R. (3d) 604 at 608 (Ont.C.A.).

182. Sony Corp. v. Time Electronics, supra n. 117.

183. R. v. Moore (1984) 45 O.R. (2d) 3 at 10 (Ont.C.A.); Reich v. College of Physicians \& Surgeons, supra n. 178 at 336; R. v. Noble (1984) 6 O.A.C. 11 at 29 (C.A.); a contrary view was taken in Helix Irvestments Ltd. v. Hunter [1984] I F.C. 262 at 276 (T.D.).

184. R. v. Chapman (1984) 3 O.A.C. 79 at 84 (C.A.). 
the right to liberty and security of the person."'185 Sub-section 11(c) protects a person charged with an of fence from being compelled to enter the witness box while s. 13 protects against testimonial compulsion ${ }^{186}$ in any proceeding where a person is exposed to a criminal charge, penalty or forfeiture as a result of having testified in an earlier proceeding. ${ }^{187}$ Neither section would provide a defendant charged with a criminal offence in an Anton Piller case with the right to remain silent in any civil proceedings arising from the same facts as the criminal charge. ${ }^{188}$ Moreover, the original action never loses its civil character.

\section{H. EXTENSIONS OF THE ANTON PILLER ORDER}

As Anton Piller orders are becoming more familiar, they are being structured to suit the particular needs of each case. Thus, in addition to being successfully used in intellectual property cases, they have been combined with Mareva injunctions and orders for the discovery and delivery up of goods' ${ }^{189}$ and extended to preserving documents not forming the subject matter of the action ${ }^{190}$ or locked in receptacles which may contain evidence related to the action. ${ }^{191}$ Furthermore, the order has been granted in matrimonial property cases, ${ }^{192}$ tax evasion actions, ${ }^{193}$ and class actions. ${ }^{194}$

\section{CONCLUSION}

During the first decade of its existence, the Anton Piller order has developed into an important weapon in the intellectual property lawyer's arsenal and it is gaining ever-increasing acceptance in areas as diverse as Australia, ${ }^{195}$ New Zealand, ${ }^{196}$ Hong Kong, ${ }^{197}$ Malaysia, ${ }^{198}$ Ireland, ${ }^{199}$ Scotland, ${ }^{200}$ Nigeria, ${ }^{201}$ and South Africa. ${ }^{202}$ Its emergence in Canada has been gradual, with only five reported case references and five more unreported decisions on record at the end of 1984. However, the lack of

185. R.L. Crain Inc. v. Couture (1983) 6 D.L.R. (4th) 478 at 502 (Sask.Q.B.).

186. R. v. Altseimer (1982) 38 O.R. (2d) 783 at 787 (C.A.).

187. Re Donald and Law Society of B.C. (1983) 2 D.L.R. (4th) 385 at 391 (B.C.C.A.).

188. Caise Populaire Laurier d'Ottawa Ltée v. Guertin (No. 2) (1984) 46 O.R. (2d) 422 (Div.Ct.); affg. 150 D.L.R. (3d) 541 at 546 (H.C.).

189. C.B.S. United Kingdom Ltd. v. Lambert [1982] 3 All E.R. 237 (C.A.); Johnson v. L \& A Philatelics Ltd. [1981] F.S.R. 286 (Q.B.).

190. Yousif v. Salama, supra n. 38; Emanuelv. Emanuel [1982] 2 All E.R. 342 (Fam.D.).

191. Hazel Grove Music Co. v. Elster Enterprises [1983] F.S.R. 379 (Ch.D.).

192. Emanuel v. Emanuel, supra n. 190; K.v. K. [1982] C.L.Y. 911 (Fam.D.).

193. Custom \& Excise Commissioners v. A.E. Hamlin \& Co., supra n. 109.

194. E.M.I. Records Ltd. v. Kudhail [1983] C.L.Y. 2968 (C.A.).

195. E.M.I. (Australia) Ltd. v. Bay Imports Ltd. [1980] F.S.R. 328 (N.S.W.S.C.).

196. Thorn E.M.I. Video Programmes Ltd. v. Kitching [1984] F.S.R. 342 (N.Z.H.C.).

197. Union Carbide Corp. v. Hing-Lin Offset Printing Co. [1981] F.S.R. 109 (H.C.H.C.).

198. Television Broadcasts Ltd. v. Mandarin Video Holdings Sdn. Bhd. [1984] F.S.R. 111 (M.H.C.).

199. House of Spring Gardens Ltd. v. Point Blank Ltd. [1980] F.S.R. 359 (1.H.C.).

200. British Phonographic Inc. Ltd. v. Cohen [1984] F.S.R. 159 (S.Ct.Sess.).

201. Ferodo Ltd. v. Unibros Stores [1980] F.S.R. 489 (N.Fed.H.C.).

202. Roamer Watch Co. v. African Textile Dist. [1980] R.P.C. 457 (S.A.S.C.). 
effective, immediate relief and the inability to control increasingly sophisticated modern day pirates under existing Canadian intellectual property legislation suggests that its growing use is as imminent as it is necessary in this country. The proliferation of such orders in England has left us with a solid base of precedents for guidance and adaptation. In certain circumstances, the order will attract challenges under the Charter of Rights, giving rise to case law that will be uniquely Canadian. As the order develops, we should remember the words of Shaw L.J. in the Anton Piller case: 203

The overriding consideration in the exercise of this salutory jurisdiction is that it is to be resorted to only in circumstances where the normal processes of the law would be rendered nugatory if some immediate and effective measure was not available. And when such an order is made, the party who has procured the court to make it must act with prudence and caution in pursuance of it.

Thus, the effectiveness of the Anton Piller order in this jurisdiction hinges on the degree of precision and restraint with which it will be composed, applied for and executed by plaintiffs' counsel. Courts will be called upon to weigh the competing interests of protecting the plaintiff's intellectual property or other rights and the defendant's historical right to enjoy the privacy of his castle and business. It is this careful balancing of social and legal interests that will ultimately shape the effectiveness of the Anton Piller order in Canada. 